\title{
POWER SPECTRA OF ULTRASONIC DOPPLER RESPONSE FROM BIOLOGICAL OBJECTS USING SYNTHETIC APERTURE TECHNIQUE
}

\author{
DIryna V. Sheina*, (D)Olexander B. Kiselov, DEven A. Barannik \\ Department of Medical Physics and Biomedical Nanotechnologies, V.N. Karazin Kharkiv National University \\ 4, Svobody Sq., 61022, Kharkiv, Ukraine \\ *Corresponding Author: i.sheina@karazin.ua \\ Received October 10, 2020; revised November 22, 2020; accepted November 30, 2020
}

\begin{abstract}
The influence of dynamic change in the steering angle of incident and scattered wave beams on the spectra of the ultrasonic Doppler response is studied on the basis of the previously developed continuum model of ultrasound waves scattering in biological objects for the case, when the Doppler response signals are averaged over the period of changing the steering angle. A general expression is obtained, which combines the resultant spectrum of the power of the ultrasonic Doppler response signal from the region of interest, the spectral characteristics of the ultrasound scatterers movement, and the sensitivity function of the diagnostic synthetic aperture system. It is shown that, as compared to the Doppler response, which is a sequence of discrete values of the response signals from different steering angles, the use of averaging allows to reduce the width of the Doppler spectra without deterioration of their resolution. It is concluded that the achievement of better spatial resolution, when using the synthetic aperture method, is possible without deterioration of the spectral characteristics and, accordingly, of the accuracy of Doppler measurements of diagnostic parameters, which are determined during the ultrasound studies. The results obtained make it possible to optimize different Doppler techniques within the framework of the general synthetic aperture method.
\end{abstract}

KEYWORDS: ultrasound, Doppler spectra, synthetic aperture technique, continuum model of scattering, sensitivity function, dynamic focusing, response formation.

Currently, promising methods of ultrasound Doppler diagnostics of the state of the cardiovascular system and soft biological tissues are widely used, rapidly developing and being introduced into medical practice $[1,2]$. Such methods include, in particular, spectral Doppler studies and Doppler color blood-flow mapping [3, 4], vector flow imaging [5, 6], tissue Doppler [7], vibro- and sonoelastography [8-11], etc. One of the major advantages of ultrasound methods, as compared to the other methods of medical diagnostics, is the possibility to obtain images in real time, what allows visualizing the dynamic structures in the human body. To provide a correct clinical interpretation [12] of the obtained data, ultrasound Doppler systems must meet certain requirements to the measurement accuracy.

In conventional Doppler ultrasound methods, to obtain an image, the diagnostic system utilizes an ultrasound transducer for sequential transmitting the ultrasonic pulses in the given direction, and for receiving the scattered waves $[1,12]$. In this case, the entire sequence of emitted pulses is characterized by the same geometry of wave fronts and direction of their propagation. This approach has a number of disadvantages associated with limitations of the resolution, the ability to obtain a sufficient amount of data for accurate resolution of flows velocity, and the ability to focus, when radiating, only at one fixed depth.

The mentioned limitations can be removed by applying the synthetic aperture data acquisition technique. A distinctive feature of the synthetic aperture method is the use of wave fronts, in particular, flat $[14,15]$, differing as to the steering direction, with subsequent coherent compounding of the recorded ultrasonic responses $[13,16,17]$. The possibility to apply the synthetic aperture technique in medical ultrasound imaging is shown by many authors $[6,13$, 18-20]. This method can be realized both in systems with a single-element transducer [21, 22], where the same element is used to transmit and receive ultrasound waves, and for systems with a multi-element transducer [17, 23, 24]. In particular, the synthetic aperture method for a circular aperture was investigated in [25].

Synthetic aperture technique is computationally intensive. Therefore, along with methods of reducing the number of computations [26], the synthetic aperture technique has received significant development with the advent of ultrasound scanners, which use parallel signal processing to produce image. [19, 27-30]. As a result of the introduction of multilinear data processing into ultrasound diagnostic systems, it became possible to visualize in-vivo blood flows using the synthetic aperture method, which, in comparison with the conventional Doppler techniques, allowed to improve spectral estimates [31], to determine the velocity vector [32], and to increase the sensitivity to slow velocity flows [33]. The methods of shear wave elastography [34, 35], estimation of local pulse wave velocity [36, 37], visualization of contrast agents [38] and of the brain activity [39] have been developed.

To date, the properties of B-images, obtained using the synthetic aperture technique, have been well studied. In particular, the dependence of the focusing quality on the number of different steering angles of plane waves has been established [40]. In [41], a technique for optimizing the parameters of plane wave radiation, which are essential for obtaining high-resolution images and estimating the velocity of both fast and slow flows, is proposed. The optimal 
values of the parameters of the amount of radiation, the steering angle of the transmitted waves, and the size of the aperture are found, with the balance between the image quality and the frame rate taken into account. In [42] different effects, that influence the focusing in this synthetic aperture vector velocity estimation method, are investigated. They include the effect of phase errors in the emitted spherical waves, motion effects, and the effect of various interpolation methods in beam formation. Verification of the vector flow methods for laminar blood flows in the common carotid artery was carried out by comparing the parameters of peak systolic velocity and volumetric blood flow, obtained by independent methods such as Spectral Doppler [43-45] and magnetic resonance angiography [46]. In vivo the accuracy of plane wave vector flow imaging was investigated for the quantitative assessment of the laminar and turbulent flows dynamics [47], as well as for determining the volumetric flow rate and experimental measurement of errors in its determination, which were described earlier theoretically [48].

To date, the theoretical description of the influence of dynamic changes in the parameters and geometry of probing ultrasonic fields on the spectra of Doppler signals and, accordingly, on the assessment of the parameters of the biological objects motion is less developed. In this paper, to study the influence of dynamic change in time of the steering angle on the spectra of ultrasonic Doppler signals, we used a continuum model of ultrasonic waves scattering by inhomogeneities of density and compressibility [49-56]. Basing on this model with stationary probing fields, used in conventional Doppler techniques, practically important solutions were obtained for the power spectra of the Doppler response in the cases of uniform, correlated, vibrational [50] and uniformly accelerated [51, 52] motion of the ultrasound scatterers. These results are utilized, in particular, in ultrasound Doppler vibroelastography, spectral Doppler studies, Doppler color blood flow mapping and other applications. In [53], the spectral characteristics of Doppler response signals were theoretically investigated for the case, when ultrasonic probing was carried out using incident and reflected wave beams with the propagation direction, periodically changing in time.

In the present paper, we investigated the influence of dynamic change in the steering angle at transmitting and receiving the wave beams on the spectral characteristics of the sensitivity function of the probing system and the spectrum of the ultrasonic Doppler response in the case, when the Doppler response signals were averaged over the period of the change in the steering angle.

\section{THEORETICAL MODEL}

This theoretical study of the process of ultrasound scattering by blood and soft tissues is based on the assumption that these biological objects interact with the emitter field as if they are an isotropic continuous medium [54-56]. Within the framework of the continuum model, the scattering occurs on inhomogeneities of the density and compressibility of the medium, and the correlation function of the ultrasonic response signals can be represented as follows [50-52, 57-60]:

$$
R(\tau)=k^{4} \iint_{R} e^{2 i \vec{k}\left(\vec{r}_{1}-\vec{r}_{0}\right)} \overline{G_{p}^{\prime *}\left(\vec{r}_{0}, t_{0}\right) G_{p}^{\prime}\left(\vec{r}_{1}, t_{1}\right)} C\left(\vec{r}_{1}-\vec{r}_{0}, \tau\right) d \vec{r}_{0} d \vec{r}_{1},
$$

where $\vec{k}$ and $k=2 \pi / \lambda$ are the wave vector and the wave number of the ultrasonic transducer field in the plane wave approximation, respectively, $\lambda$ is the wavelength, $c$ is the velocity of ultrasonic waves in the medium, $G_{p}^{\prime}(\vec{r}, t)$ is the complex function of the ultrasound system sensitivity distribution over the field, which is determined by the shape of the probing pulses, as well as by the amplitude and phase characteristics of the incident and reflected wave beams. The value $C\left(\vec{r}_{1}-\vec{r}_{0}, \tau\right)$ is the correlation function, which describes the space-time characteristics of fluctuations in density and compressibility. In the case of stationary motion of the ultrasound scatterers after averaging over the statistical ensemble, this function depends only on the difference coordinate and the difference time $\tau=t_{1}-t_{0}$.

Regardless of the method for determining the Doppler shift frequency and the spectral characteristics of Doppler signals, described in [61], when the synthetic aperture method is used, the sensitivity function also depends on time. The bar in the expression (1) means averaging over the initial moment of time $t_{0}$ since for a complete averaging of the autocorrelation function, it is necessary to take into account different initial steering angles at different $t_{0}$. Whereas for both stationary and non-stationary motion of ultrasound scatterers, the correlation function (1) turns out, in reality, to be a function of only the difference coordinate and the difference time.

The power spectrum of the Doppler signal is the Fourier transform of the correlation function

$$
S(\omega)=\int R(\tau) e^{i \omega \tau} d \tau
$$

at calculation of which it is necessary to take into account the explicit time dependence of the ultrasound system sensitivity function. 


\section{RESULTS AND DISSCUSSION}

There are two possible ways of generating an ultrasonic Doppler signal using responses, obtained for different steering angles of a dynamically changing sensitivity function. In one of them, the Doppler response is a sequence of discrete values of the response signals for a sequence of different steering angles. In this case, the resultant power spectrum of the Doppler signal can be written as follows [53]:

$$
S\left(\omega_{k}\right)=\frac{k^{4}}{(2 \pi)^{3}} \sum_{j=-\infty}^{\infty} \int d \vec{q} C\left(\vec{q}, \omega_{k}-\omega_{j}\right)\left|G\left(\vec{q}+2 \vec{k}, \omega_{j}\right)\right|^{2},
$$

where $\omega_{k}=2 \pi k / T$ is the variable of the Fourier series expansion, and $T$ is the period of the steering angles change. It is obvious, that in this case a change in the direction of the wave vector and the sensitivity function in time leads to the corresponding change in the Doppler angle $\vartheta$ between the wave vector and the direction of the motion velocity. As a result, even at a constant velocity of the ultrasound scatterers $V$, the measured speed $V \cos \vartheta$ also constantly increases or decreases, depending on whether the angle $\vartheta$ decreases or increases. This situation is physically equivalent to the accelerated movement of ultrasound scatterers, what leads to broadening of the Doppler signal spectrum, as shown in [52]. This circumstance is a disadvantage, as compared to the traditional methods of Doppler ultrasound probing.

The other method of generating an ultrasonic Doppler signal is that, at which the discrete values are obtained by summing the discrete values of the response signals for different steering angles over the entire period of changing the angles $T$. In the sense, such summation means averaging over the period $T$, taking into account of which the sensitivity function $G_{p}^{\prime}(\vec{r}, t)$ is described by the expression

$$
\overline{G_{p}^{\prime}(\vec{r}, t)}=\int_{-T / 2}^{T / 2} G_{p}^{\prime}\left(\vec{r}, t+t^{\prime}\right) d t^{\prime}
$$

Substitution of formula (4) into (1) leads to the following expression for the autocorrelation function:

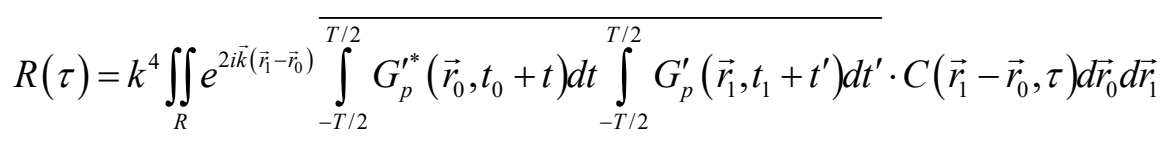

As in the derivation of equation (3), we assume that the registration of the ultrasonic Doppler response signals is performed within a finite time interval $T$. In the case of a periodic change in the sensitivity function, it is natural to use for this value, in particular, this period of change. In general, the periodic extension of the sensitivity functions and the correlation function of scattering fluctuations allows using their expansion in Fourier series:

$$
\begin{gathered}
G_{p}^{\prime *}\left(\vec{r}_{0}, t_{0}+t^{\prime}\right)=\sum_{n=-\infty}^{\infty} e^{2 \pi n\left(t_{0}+t^{\prime}\right) / T} G_{p}^{\prime *}\left(\vec{r}_{0}, \frac{2 \pi}{T} n\right), \\
G_{p}^{\prime}\left(\vec{r}_{1}, t_{1}+t^{\prime}\right)=\sum_{j=-\infty}^{\infty} e^{-2 \pi j\left(t_{1}+t^{\prime}\right) / T} G_{p}^{\prime}\left(\vec{r}_{1}, \frac{2 \pi}{T} j\right)=\sum_{j=-\infty}^{\infty} e^{-2 \pi j\left(t^{\prime}+t_{0}+\tau\right) / T} G_{p}^{\prime}\left(\vec{r}_{1}, \frac{2 \pi}{T} j\right) \\
C\left(\vec{r}_{1}-\vec{r}_{0}, \tau\right)=\frac{1}{(2 \pi)^{3}} \int d \vec{q} e^{i \vec{q}\left(\vec{r}_{1}-\vec{r}_{0}\right)} \sum_{m=-\infty}^{\infty} e^{-2 \pi i m \tau / T} C\left(\vec{q}, \frac{2 \pi}{T} m\right)
\end{gathered}
$$

Here, the value $C(\vec{q}, 2 \pi m / T)$ describes the spectral components of the correlation function of the space-time characteristics of fluctuations.

Substituting these expressions into formula (5), we obtain a general expression for the spectrum of the ultrasonic Doppler response, with the averaging over the period taken into account

$$
S\left(\omega_{k}\right)=\sum_{n, j, m=-\infty}^{\infty} \frac{k^{4}}{(2 \pi)^{3}} \int d \tau e^{i \omega_{k} \tau} \int d \vec{q} \iint_{R} d \vec{r}_{1} d \vec{r}_{0} e^{i(\vec{q}+2 \vec{k})\left(\vec{r}_{-}-\vec{r}_{0}\right)} \times
$$




$$
\times \int_{-T / 2}^{T / 2} e^{2 \pi i n\left(t_{0}+t\right) / T} G_{p}^{\prime *}\left(\vec{r}_{0}, \frac{2 \pi}{T} n\right) d t \int_{-T / 2}^{T / 2} e^{-2 \pi i j\left(t^{\prime}+t_{0}+\tau\right) / T} G_{p}^{\prime}\left(\vec{r}_{1}, \frac{2 \pi}{T} j\right) d t^{\prime} \cdot e^{-2 \pi i m \tau / T} C\left(\vec{q}, \frac{2 \pi}{T} m\right)
$$

For convenience, we rearrange the factors in the last expression as follows:

$$
\begin{array}{r}
S\left(\omega_{k}\right)=\sum_{n, j, m=-\infty}^{\infty} \frac{k^{4}}{(2 \pi)^{3}} \int d \tau e^{i \tau\left(\omega_{k}-\frac{2 \pi j}{T}-\frac{2 \pi m}{T}\right)} \int d \vec{q} \iint_{R} d \vec{r}_{1} d \vec{r}_{0} e^{i(\vec{q}+2 \vec{k})\left(\vec{r}_{1}-\vec{r}_{0}\right)} \times \\
\times G_{p}^{\prime *}\left(\vec{r}_{0}, \frac{2 \pi}{T} n\right) G_{p}^{\prime}\left(\vec{r}_{1}, \frac{2 \pi}{T} j\right) \int_{-T / 2}^{T / 2} e^{\frac{2 \pi i t t}{T}} d t \int_{-T / 2}^{T / 2} e^{-\frac{2 \pi j i j^{\prime}}{T}} d t^{\prime} \cdot e^{\frac{2 \pi t_{0}}{T}(n-j)} C\left(\vec{q}, \frac{2 \pi}{T} m\right)
\end{array}
$$

Then calculating the average value over the initial moment of time leads to the Kronecker symbol

$$
e^{\overline{\frac{2 \pi i t_{0}}{T}(n-j)}}=\frac{1}{T} \int_{-T / 2}^{T / 2} e^{\frac{2 \pi i t_{0}}{T}(n-j)} d t_{0}=\delta_{n, j}
$$

what allows summing up over one of the indices in (6):

$$
\begin{aligned}
& S\left(\omega_{k}\right)=\sum_{j, m=-\infty}^{\infty} \frac{k^{4}}{(2 \pi)^{3}} \int d \tau e^{i \tau\left(\omega_{k}-\frac{2 \pi j}{T}-\frac{2 \pi m}{T}\right)} \int d \vec{q} \iint_{R} d \vec{r}_{1} d \vec{r}_{0} e^{i(\vec{q}+2 \vec{k})\left(\vec{r}_{1}-\vec{r}_{0}\right)} \times \\
& \times G_{p}^{\prime *}\left(\vec{r}_{0}, \frac{2 \pi}{T} j\right) G_{p}^{\prime}\left(\vec{r}_{1}, \frac{2 \pi}{T} j\right) \int_{-T / 2}^{T / 2} e^{\frac{2 \pi i j t}{T}} d t \int_{-T / 2}^{T / 2} e^{-\frac{2 \pi i j t^{\prime}}{T}} d t^{\prime} \cdot C\left(\vec{q}, \frac{2 \pi}{T} m\right)
\end{aligned}
$$

Then, the integration over time leads to a similar outcome, as a result of which we find:

$$
\int_{-T / 2}^{T / 2} e^{\frac{2 \pi i j t}{T}} d t \int_{-T / 2}^{T / 2} e^{-\frac{2 \pi i j t^{\prime}}{T}} d t^{\prime}=T^{2} \cdot \delta_{j, 0}
$$

Given this, after summing over the index $j$, the expression for $S\left(\omega_{k}\right)$ takes the form:

$$
S\left(\omega_{k}\right)=\sum_{m=-\infty}^{\infty} \frac{k^{4}}{(2 \pi)^{3}} \cdot T^{2} \int d \tau e^{i \tau\left(\omega_{k}-\frac{2 \pi m}{T}\right)} \int d \vec{q} \iint_{R} d \vec{r}_{1} d \vec{r}_{0} e^{i(\vec{q}+2 \vec{k})\left(\vec{r}_{1}-\vec{r}_{0}\right)} \cdot G_{p}^{*}\left(\vec{r}_{0}, 0\right) G_{p}^{\prime}\left(\vec{r}_{1}, 0\right) \cdot C\left(\vec{q}, \frac{2 \pi}{T} m\right)
$$

Besides,

$$
\int d \tau e^{i \tau\left(\omega_{k}-\frac{2 \pi m}{T}\right)}=\delta_{\omega_{k}, 2 \pi m / T}
$$

as a result of which we find

$$
S\left(\omega_{k}\right)=\frac{k^{4}}{(2 \pi)^{3}} T^{2} \int d \vec{q} \iint_{R} d \vec{r}_{1} d \vec{r}_{0} e^{i(\vec{q}+2 \vec{k})\left(\vec{r}_{1}-\vec{r}_{0}\right)} \cdot G_{p}^{\prime *}\left(\vec{r}_{0}, 0\right) G_{p}^{\prime}\left(\vec{r}_{1}, 0\right) \cdot C\left(\vec{q}, \omega_{k}\right) .
$$

By definition of the three-dimensional Fourier transform of the function, we have

$$
\int_{R} d \vec{r} e^{i(\vec{q}+2 \vec{k}) \vec{r}} G_{p}^{\prime}(\vec{r}, 0)=G(\vec{q}+2 \vec{k}, 0) .
$$


Then, taking into account this Fourier transform, we obtain the final form of the power spectrum of the ultrasonic Doppler response signal in the considered case of averaging over the period $T$ :

$$
S\left(\omega_{k}\right)=\frac{k^{4}}{(2 \pi)^{3}} T^{2} \int d \vec{q} C\left(\vec{q}, \omega_{k}\right)|G(\vec{q}+2 \vec{k}, 0)|^{2} .
$$

In contrast to the expression obtained in [52] and expression (3), formula (7) does not contain the frequency convolution of the correlation function of space-time fluctuations and the sensitivity function. This means that the width of the Doppler signal spectrum is narrower than that in the first version of the ultrasonic Doppler response signal generation. In this sense, formula (7) is similar to the integral expression for the power spectrum

$$
S=\frac{k^{4}}{(2 \pi)^{3}} \int d \vec{q} C(\vec{q}, \omega)|G(\vec{q}+2 \vec{k})|^{2}
$$

which was obtained for stationary probing fields, used in conventional methods of Doppler probing [50]. In this case, sequential radiation in the given direction of ultrasonic pulses is used, which is characterized by the same spatial geometry of wave fronts and by the same direction of radiation. At the same time, the application of such techniques in practice has some disadvantages. The first of them is associated with a fixed focal length at transmitting, what worsens the spatial resolution, and the second one is caused by a long data acquisition time for imaging, thus, the attainable frame frequency is severely limited.

Coherent compounding of response signals in the synthetic aperture method provides high resolution for radiation in the entire range of depths. The resulting expression (7) shows that such an improvement in resolution can be achieved also with ultrasonic Doppler probing without deterioration of spectral characteristics and, in particular, the width of the spectrum of the ultrasonic Doppler response signals. The accuracy of measurement of the Doppler spectrum average frequency is discussed, as a rule [55, 62], proceeding from the known Nyquist limit and the RaoCramer inequality. Both of these criteria lead to the requirement for the minimum bandwidth of the Doppler signal. The results obtained make it possible to optimize specific Doppler and spectral-Doppler ultrasound medical diagnostic techniques, implemented by using the synthetic aperture technique.

\section{CONCLUSIONS}

To increase the efficiency of ultrasonic Doppler diagnostic methods, it is important to study the Doppler response spectra under the given area of interest, which directly affect the accuracy of estimation of the investigated parameters of the biological objects motions. Therefore, it is still relevant to study the influence of the factor of dynamic changes in the parameters and geometry of probing ultrasonic fields on the spectra of Doppler signals and, accordingly, on the estimates of the parameters of the biological objects motion.

This paper presents a general theory, which is suitable for describing the spectral characteristics of ultrasonic Doppler signals, using the up-to-date technique of dynamic focusing of the emitted ultrasonic beams by the synthetic aperture method. In accordance with this technique, each probing pulse of ultrasound waves is characterized by its own direction of propagation, and coherent compounding of ultrasonic response signals, received from a set of such probing pulses, is used for focusing the waves at transmitting and forming the image of a biological object. The influence of dynamic change in the angle of transmitting and receiving the wave beams on the spectral characteristics of the sensitivity function of the probing system and the spectrum of ultrasonic Doppler response, in the case, when the Doppler response signals are averaged over the period of the change in the steering angle of probing, are studied. A general expression is obtained, which connects the resultant power spectrum of the ultrasonic Doppler response signal, the spectral characteristics of the ultrasound scatterers movement, and the sensitivity function of the system. The results, obtained in this paper, show the difference between two possible strategies for collecting information while forming the Doppler signals, and can contribute to the improvement of various Doppler techniques within the framework of the general synthetic aperture method.

\section{ORCID IDs}

IDryna V. Sheina, https://orcid.org/0000-0002-0293-4849; DOlexander B. Kiselov, https://orcid.org/0000-0002-7585-5180; (D)Evgen A. Barannik, https://orcid.org/0000-0002-3962-9960

\section{REFERENCES}

[1] P.N.T. Wells, Phys. Med. Biol. 51(13), R83-R98 (2006), https://doi.org/10.1088/0031-9155/51/13/R06.

[2] P.R. Hoskins, K. Martin, and A. Thrush (eds.), Diagnostic Ultrasound: Physics and Equipment, 3rd ed. (CRC Press, Boca Raton, 2019), in https://doi.org/10.1201/9781138893603.

[3] P.N.T. Wells, Eur. J. Ultrasound, 7(1), 3-8 (1998), https://doi.org/10.1016/S0929-8266(98)00006-8.

[4] D.H. Evans, Proc. Inst. Mech. Eng. H, 224(2), 241-253 (2009), https://doi.org/10.1243/09544119JEIM599. 
[5] J.A. Jensen, S.I. Nikolov, A.C.H. Yu, and D. Garcia, IEEE Trans. Ultrason. Ferroelectr. Freq. Contr. 63(11), 1704-1721 (2016), http://doi.org/10.1109/TUFFC.2016.2600763.

[6] J.A. Jensen, S.I. Nikolov, A.C.H. Yuand, and D. Garcia, IEEE Trans. Ultrason. Ferroelectr. Freq. Contr. 63(11), 1722-1732 (2016), http://doi.org/10.1109/TUFFC.2016.2598180.

[7] N. Pulkovski, P. Schenk, N.A. Maffiulettiand, and A.F. Mannion, Muscle \& Nerve, 37(5), 638-649 (2008), https://doi.org/10.1002/mus.20996.

[8] L. Gao, K.J. Parker, R.M. Lerner, and S.F. Levinson, Ultrasound Med. Biol. 22(8), 959-977 (1996), https://doi.org/10.1016/S0301-5629(96)00120-2.

[9] J. Ophir, S.K. Alam, B.S. Garra, F. Kallel, E. Konofagou, T.A. Krouscop, C.R.B. Merritt, R. Righetti, R. Souchon, S. Srinivasan, and T. Varghese, J. Med. Ultrasonics, 29(4), 155-171 (2002), https://doi.org/10.1007/BF02480847.

[10] P.N. Wells, and H.D. Liang, J. R. Soc. Interface, 8(64), 1521-1549 (2011), https://doi.org/10.1098/rsif.2011.0054.

[11] K.J. Parker, M.M. Doyley, and D.J. Rubens, Phys. Med. Biol. 56, R1-R29 (2011), https://doi.org/10.1088/0031-9155/56/1/R01.

[12] C.R. Hill, and J.C. Bamber, in: Physical principles of medical ultrasonics, edited by C.R. Hill, J.C. Bamber, G.R. ter Haar (John Wiley \& Sons, West Sussex, 2004), pp. 255-302.

[13] J.A. Jensen, S.I. Nikolov, K.L. Gammelmarkand, and M.H. Pedersen, Ultrasonics, 44(1), e5-e15 (2006), https://doi.org/10.1016/j.ultras.2006.07.017.

[14] M. Tanter, J. Bercoff, L. Sandrin, and M. Fink, IEEE Trans. Ultrason. Ferroelectr. Freq. Contr. 49(10), 1363-1374 (2002), https://doi.org/10.1109/TUFFC.2002.1041078.

[15] J.Y. Lu, IEEE Trans. Ultrason. Ferroelec. Freq. Contr. 44(4), 839-856 (1997), https://doi.org/10.1109/58.655200.

[16] S. Nikolov, Synthetic aperture tissue and flow ultrasound imaging, Ph.D. dissertation, Dept. Electr. Eng., Tech. Univ. Denmark, (Lyngby, Denmark, 2001).

[17] M. Karaman, P.C. Li, and M. O'Donnell, IEEE Trans. Ultrason. Ferroelec. Freq. Contr. 42(3), 429-442 (1995), https://doi.org/10.1109/58.384453.

[18] M.H. Pedersen, K.L. Gammelmark, and J.A. Jensen, Ultrasound Med. Biol. 33(1), 37-47 (2007), https://doi.org/10.1016/j.ultrasmedbio.2006.07.041.

[19] M. Tanter and M. Fink, IEEE Trans. Ultrason. Ferroelectr. Freq. Control. 61(1), 102-119 (2014), https://doi.org/10.1109/TUFFC.2014.6689779.

[20] H. Yao Synthetic Aperture Methods for Medical Ultrasonic Imaging, Dept. Inform. Univ. Oslo, (University of Oslo, Oslo, 1997).

[21] D.K. Peterson, and G.S. Kino, IEEE Trans. Son. Ultrason. 31(4), 337-351 (1984), https://doi.org/10.1109/T-SU.1984.31514.

[22] J.T. Ylitalo, and H. Ermert, IEEE Trans. Ultrason. Ferroelec. Freq. Contr. 41(3), 333-339 (1994), https://doi.org/10.1109/58.285467.

[23] G.R. Lockwood, J.R. Talman, and S.S. Brunke, IEEE Trans. Ultrason. Ferroelec. Freq. Contr. 45(4), 980-988 (1998), https://doi.org/10.1109/58.710573.

[24] C.R. Hazard, and G.R. Lockwood, IEEE Trans. Ultrason. Ferroelec. Freq. Contr. 46(4), 972-980 (1999), https://doi.org/10.1109/58.775664.

[25] M. O’Donnell, and L.J. Thomas, IEEE Trans. Ultrason. Ferroelec. Freq. Contr. 39(3), 366-380 (1992), https://doi.org/10.1109/58.143171.

[26] R. Moshavegh, J. Jensen, C.A. Villagómez-Hoyos, M.B. Stuart, M.C. Hemmsen, and J.A. Jensen, in: Proceedings of SPIE Medical Imaging (San Diego, California, United States, 2016), pp. 97900Z-97900Z-9, https://doi.org/10.1117/12.2216506.

[27] L. Sandrin, S. Catheline, M. Tanter, and M. Fink, in: Acousical Imaging, edited by M. Halliwell, P. N. T. Wells (Springer, Boston, MA, 2002), pp. 485-492, https://doi.org/10.1007/0-306-47107-8_68.

[28] J. A.Jensen, O. Holm, L.J. Jerisen, H. Bendsen, S.I. Nikolov, B.G. Tomov, P. Munk, M. Hansen, K. Salomonsen, J. Hansen, K. Gormsen, H.M. Pedersen, and K.L. Gammelmark, IEEE Trans. Ultrason. Ferroelectr. Freq. Contr. 52(5), 881-891 (2005), https://doi.org/10.1109/TUFFC.2005.1503974.

[29] J. Lu, J. Cheng, and J. Wang, IEEE Trans. Ultrason. Ferroelec. Freq. Contr. 53(10), 1796-1812(2006), https://doi.org/10.1109/TUFFC.2006.112.

[30] P. Tortoli, L. Bassi, E. Boni, A. Dallai, F. Guidi, and S. Ricci, IEEE Trans. Ultrason. Ferroelec.Freq. Contr. 56(10), 2207-2216 (2009), https://doi.org/10.1109/TUFFC.2009.1303.

[31] S.I. Nikolov, and J.A. Jensen, IEEE Trans. Ultrason. Ferroelec. Freq. Contr. 50(7), 848-856 (2003), https://doi.org/10.1109/TUFFC.2003.1214504

[32] J.A. Jensen, and N. Oddershede, IEEE Trans. Med. Imag. 25(12), 1637-1644(2006), https://doi.org/10.1109/TMI.2006.883087.

[33] J. Bercoff, G. Montaldo, T. Loupas, D. Savery, F. Meziere, M. Fink, and M. Tanter, IEEE Trans. Ultrason. Ferroelec. Freq. Contr. 58(1), 134-147 (2011), https://doi.org/10.1109/TUFFC.2011.1780.

[34] L. Sandrin, M. Tanter, S. Catheline, and M. Fink, IEEE Trans. Ultrason. Ferroelec. Freq. Contr. 49(4), $426-435$ (2002), https://doi.org/10.1109/58.996560.

[35] J. Bercoff , M. Tanter, and M. Fink, IEEE Trans. Ultrason. Ferroelec. Freq. Contr. 51(4), 396-409 (2004), https://doi.org/10.1109/TUFFC.2004.1295425.

[36] H. Hasegawa, and H. Kanai, IEEE Trans. Ultrason. Ferroelec. Freq. Contr. 55(12), 2626-2639 (2008), https://doi.org/10.1109/TUFFC.2008.978

[37] J. Vappou, J. Luo, and E.E. Konofagou, Am. J. Hypertens. 23(4), 393-398 (2010),https://doi.org/10.1038/ajh.2009.272.

[38] O. Couture, M. Fink, and M. Tanter, IEEE Trans. Ultrason. Ferroelec.Freq. Contr. 59(12), 2676-2683 (2012), https://doi.org/10.1109/TUFFC.2012.2508.

[39] E. Mace, G. Montaldo, I. Cohen, M. Baulac, M. Fink, and M. Tanter, Nature methods, 8(8), $662-664$ (2011), https://doi.org/10.1038/nmeth.1641.

[40] G. Montaldo, M. Tanter, J. Bercoff, N. Benech, and M. Fink, IEEE Trans. Ultrason. Ferroelectr. Freq. Contr. 56(3), 489-506 (2009), https://doi.org/10.1109/TUFFC.2009.1067. 
[41] J. Jensen, M.B. Stuart, and J.A. Jensen, IEEE Trans. Ultrason. Ferroelectr. Freq. Contr. 63(11), 1922-1934 (2016), https://doi.org/10.1109/TUFFC.2016.2591980.

[42] N. Oddershedeand, and J.A. Jensen, IEEE Trans. Ultrason. Ferroelec. Freq. Contr. 54(9), 1811-1825 (2007), https://doi.org/10.1109/TUFFC.2007.465.

[43] M.M. Pedersen, M.J. Pihl, P. Haugaard, J.M. Hansen, K.L. Hansen, M.B. Nielsen, and J.A. Jensen, Ultrasound Med. Biol. 38(1), 145-151(2012), https://doi.org/10.1016/j.ultrasmedbio.2011.10.003.

[44] P. Tortoli, M. Lenge, D. Righi, G. Ciuti, H. Liebgott, and S. Ricci, Ultrasound Med. Biol. 41(5), 1354-1362 (2015), https://doi.org/10.1016/j.ultrasmedbio.2015.01.008.

[45] I.K. Ekroll, T. Dahl, H. Torp, and L. Løvstakken, Ultrasound Med. Biol. 40(7), 1629-1640 (2014), https://doi.org/10.1016/j.ultrasmedbio.2014.01.021.

[46] K.L. Hansen, J. Udesen, N. Oddershede, L. Henze, C. Thomsen, J.A. Jensen, and M.B. Nielsen, Ultrasonics, 49(8), 659-667 (2009), https://doi.org/10.1016/j.ultras.2009.04.002.

[47] J. Jensen, M.S. Traberg, C.A. Villagómez Hoyos, J.B. Olesen, B. Tomov, R. Moshavegh, M.B. Stuart, C. Ewertsen, K.L. Hansen, M.B. Nielsen, and J.A. Jensen, in: 2017 IEEE International Ultrasonics Symposium (IUS), (IEEE, Washington, DC, 2017), pp. 1-4, https://doi.org/10.1109/ULTSYM.2017.8092535.

[48] J. Jensen, J.B. Olesen, M.B. Stuart, P.M. Hansen, M.B. Nielsen, and J.A. Jensen, Ultrasonics, 70, 136-146 (2016), https://doi.org/10.1016/j.ultras.2016.04.023.

[49] E.A. Barannik, Ultrasonics, 39(2), 311-317 (2001), https://doi.org/10.1016/S0041-624X(01)00059-2.

[50] I.V. Skresanova, and E.A. Barannik, Ultrasonics, 52(5), 676-684 (2012), https://doi.org/10.1016/j.ultras.2012.01.014.

[51] E.A. Barannik, and O.S. Matchenko, East Eur. J. Phys. 2(1), 36-40 (2015), https://doi.org/10.26565/2312-4334-2015-1-05. (in Russian)

[52] O.S. Matchenko, and E.A. Barannik, Acoust. Phys. 63(5), 596-603 (2017), https://doi.org/10.1134/ S1063771017050086.

[53] E.A. Barannik, and O.S. Matchenko, East Eur. J. Phys. 3(2) 61-64 (2016), https://doi.org/10.26565/2312-4334-2016-2-08. (in

[54] B.A.J. Angelsen, IEEE Trans. Biomed. Eng. BME-27(2), 61-67 (1980), https://doi.org/10.1109/TBME.1980.326708.

[55] P.J. Fish, in: PhysicalPrinciplesofMedical Ultrasonics, edited by C.R. Hill (EllisHorwood, Chichester, 1986), pp. 338-376.

[56] R.J. Dickinson, and D.K. Nassiri, in: Physical principles of medical ultrasonics, edited by C. R. Hill, J. C. Bamber, G. R. terHaar (John Wiley \& Sons, West Sussex, 2004), p. 191-222.

[57] E.A. Barannik, Sov. Phys. Acoust. 38 (2), 237-244 (1992). (in Russian) http://www.akzh.ru/pdf/1992_2_237-244.pdf. (in Russian)

[58] E.A. Barannik, Acoust. Phys. 39 (5), 939-941 (1993). (in Russian), http://www.akzh.ru/pdf/1993_5_939-941.pdf. (in Russian)

[59] E.A. Barannik, Acoust. Phys. 40(2), 212-214 (1994), http://www.akzh.ru/pdf/1994_2_212-214.pdf. (in Russian)

[60] E.A. Barannik, Acoust. Phys. 43(4), 453-457 (1997),http://www.akzh.ru/pdf/1997_4_453-457.pdf. (in Russian)

[61] R.J. Eckersley, and J.C. Bamber, in: Physical principles of medical ultrasonics, edited by C.R. Hill, J.C. Bamber, G.R. ter Haar (John Wiley \& Sons, West Sussex, 2004), p. 303-336.

[62] W. Gilson, and S. Orphanoudakis, in: Proceedings of the Annual International Conference of the IEEE Engineering in Medicine and Biology Society (IEEE, New Orleans, 1988), pp. 473-474, https://doi.org/10.1109/IEMBS.1988.94615.

\section{СПЕКТРИ ПОТУЖНОСТІ УЛЬТРАЗВУКОВОГО ДОППЛЕРІВСЬКОГО ВІДГУКУ БІОЛОГІЧНИХ ОБ'ЄКТІВ ПРИ ЗАСТОСУВАННІ ТЕХНОЛОГІЇ СИНТЕЗОВАНОЇ АПЕРТУРИ \\ І.В. Шеіна", О.Б. Кісельов, С.О. Баранник}

Кафедра медичної фізики та біомедичних нанотехнологій,Харківський начіональний університет імені В.Н. Каразіна м. Свободи 4, Харків, 61022, Україна

На основі розвиненої раніше континуальної моделі розсіювання ультразвукових хвиль у біологічних об'єктах досліджено вплив динамічної зміни ракурсів випромінювання та прийому ультразвукових пучків хвиль на спектри ультразвукового допплерівського відгуку у випадку, коли проводиться усереднення сигналів допплерівського відгуку за періодом зміни кутів зондування. Здобуто загальний вираз, що пов'язує повний спектр потужності сигналу ультразвукового допплерівського відгуку з області інтересу, спектральні характеристики руху розсіювачів ультразвуку та функції чутливості діагностичної системи 3 синтезованою апертурою. Показано, що порівняно 3 допплерівським відгуком, який являє собою послідовність дискретних значень сигналів відгуку з різних ракурсів, застосування усереднення дає змогу зменшити ширину допплерівських спектрів без погіршення роздільної здатності. Зроблено висновок про те, що досягнення кращої роздільної здатності при застосування методу синтезованої апертури можливе без погіршення спектральних характеристик i, відповідно, точності допплерівських вимірювань діагностичних параметрів, що визначають в ході ультразвукових досліджень. Одержані результати дають змогу оптимізувати різні допплерівські техніки в межах загального методу синтезованої апертури.

КЛЮЧОВІ СЛОВА: ультразвук, допплерівський спектр, метод синтезованої апертури, континуальна модель розсіяння, функція чутливості, динамічне фокусування, формування відгуку

\section{СПЕКТРЫ МОЩНОСТИ УЛЬТРАЗВУКОВОГО ДОППЛЕРОВСКОГО ОТКЛИКА БИОЛОГИЧЕСКИХ ОБЬЕКТОВ ПРИ ИСПОЛЬЗОВАНИИ ТЕХНОЛОГИИ СИНТЕЗИРОВАННОЙ АПЕРТУРЫ}

\section{И.В. Шеина, А.Б. Киселёв, Е.А. Баранник}

Кафедра медииинской физики и биомедицинских нанотехнологий,

Харьковский национальный университет имени В.Н. Каразина

пл. Свободы 4, Харьков, 61022, Украина

На основании развитой ранее континуальной модели рассеяния ультразвуковых волн в биологических объектах изучено влияние динамического изменения ракурсов излучения и приёма пучков волн на спектры ультразвукового допплеровского отклика в случае, когда производится усреднение сигналов допплеровского отклика по периоду изменения углов 
зондирования. Получено общее выражение, связывающее полный спектр мощности сигнала ультразвукового допплеровского отклика из области интереса, спектральные характеристики движения рассеивателей ультразвука и функции чувствительности диагностической системы с синтезированной апертурой. Показано, что по сравнению с допплеровским откликом, который представляет собой последовательность дискретных значений сигналов отклика с разных ракурсов, применение усреднения позволяет уменьшить ширину допплеровских спектров без ухудшения разрешающей способности. Сделан вывод о том, что достижение лучшей пространственной разрешающей способности при использовании метода синтезированной апертуры возможно без ухудшения спектральных характеристик и, соответственно, точности допплеровских измерений диагностических параметров, определяемых в ходе ультразвуковых исследований. Полученные результаты дают возможность оптимизировать разные допплеровские техники в рамках общего метода синтезированной апертуры.

КЛЮЧЕВЫЕ СЛОВА: ультразвук, допплеровский спектр, технология синтезированной апертуры, континуальная модель рассеяния, функция чувствительности, динамическое фокусирование, формирование отклика 